IInnlegg på inntil $\mathbf{4 0 0}$ ord lastes opp i http://mc.manuscriptcentral.com/tidsskriftet.

Redaksjonen forbeholder seg retten til å foreta redaksjonelle endringer.

Forfattere av vitenskapelige artikler har tilsvarsrett (jf. Vancouver-gruppens regler).

\section{Feil om legionærsykdom i sykehus}

I Tidsskriftet nr. 16/2011 skriver Marjut Sarjomaa og medarbeidere om forebygging av legionærsykdom i sykehus (1). Dessverre inneholder artikkelen tre faktafeil.

- ICA-systemet er godkjent for alminnelig bruk, se Mattilsynets godkjente vannbehandlingsprodukter (2) og også en tidligere presentasjon i Tidsskriftet (3).

- Sykehuset Telemark, Skien, har siden en måned etter installasjon/igangkjøring vært legionellafritt bortsett fra en prøve for ca. tre år siden i en dusj som ikke var i bruk. På dette tappepunktet lot man vannet renne et par-tre minutter (kaldt og varmt). Siden er det ikke blitt påvist Legionella. Dette er dokumentert ved vannprøver der man det første året tok vannprøver hver måned, deretter annenhver måned i to år. Nå tas det vannprøver to ganger per år. (Artikkelens avsnitt om erfaringer fra Sykehuset Telemark, Skien.)

- Kobber i vannprøvene viser stabilt litt i underkant av i snitt $150 \mu \mathrm{g} /$ liter mot 311 $\mu \mathrm{g} /$ liter i snitt før installasjon av ICA-systemet ( 29 vannprøver ble tatt + råvannsprøve), altså redusert utslipp av tungmetaller $i$ avløp til rensestasjon/landbruksslam og rene rør. Dette fører til en betydelig miljøgevinst i tillegg til de andre fordelene med ICA-systemet: Drikkevann uten fare for legionellaoppblomstering eller Escherichia coli-angrep, samt energibesparelse fordi man slipper ekstremoppvarming av vann, vannbesparelse og arbeidstidsbesparelse.

I artikkelens avslutningskapittel påstås det at økt kobberinnhold øker faren for farging av sykehusinstrumenter. Dersom denne påstand er riktig, er situasjonen på Sykehuset Telemark betydelig forbedret da kobberinnholdet er redusert med mer en $50 \%$ fra før behandlingen av anlegget tok til. Vi tror biofilm fra rørene og $\mathrm{Ag} / \mathrm{Cu}$ i kombinasjon kan være sannsynlig årsak. Biofilmen forsvinner litt og litt fra røranleggets innside og problemet forsvinner etter hvert. Det kan være fornuftig å sette på små, rimelige filtre før vannet går inn i maskiner som vasker og desinfiserer medisinsk utstyr, inntil rørene er rene. Skitten må ut, dessverre tar det litt tid. Det sies i artikkelen at ICA-systemet er en relativt dyr investering, ca. 750000 kroner med årlige driftskostnader på ca. 75000 kroner. Til det skal det sies at vi regner tiden det tar før nytten overstiger investeringene, såkalt tilbakebetalingstid (pay-back-tid) på slike installasjoner i snitt til ca 2,5-3 år. I tilfellet Syke- huset Telemark har vi fått opplyst derifra at deres tilbakebetalingstid var ca. 1,5 år.

\section{Knut Grimsen}

Aquanoah AS

Knut Grimsen (f. 1949) er økonom. Han etablerte Aquanoah AS i 2002 og har i fem år arbeidet med bekjempelse av bakterier i interne rørsystemer.

Oppgitte interessekonflikter: Han er største aksjonær og daglig leder.

\section{Litteratur}

1. Sarjomaa M, Urdahl P, Ramsli E et al. Forebygging av legionærsykdom i sykehus. Tidsskr Nor Legeforen 2011; 131: 1554-7.

2. Mattilsynet. http://mattilsynet.no/vann/vannverk/ godkjente_vannbehandlingsprodukter_9242 (26.10.2011).

3. Braaten KE. Bekjemper legionella med kobber og sølv. Tidsskr Nor Legeforen 2010; 130: 1510.

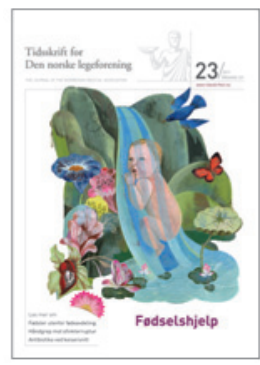

\section{Tro og moral i bistandsarbeidet}

Magnus Røger \& Håkon Bleken har i Tidsskriftet nr. 23/2011 et kritisk innlegg til en kronikk av Berit Austveg og undertegnede $(1,2)$. Vi har noen kommentarer til deres fremstilling.

Vi driver ikke kamp mot kirken som sådan, men påpeker at trosretninger og kirkebaserte ideologier har vært med på å påvirke mange ansvarlige politikeres respons på to store folkehelsetragedier: abortdødelighet som rammer mange fattige unge kvinner, og hiv/aids som rammer fattige, unge mennesker i blant annet Afrika. Konservative holdninger til abort fra givere som f.eks. USA, har gjort at organisasjoner som jobber for kvinners helse i Afrika har mistet massiv støtte. Uklare meldinger omkring bruk av kondom har gjort at unge mennesker har hatt vanskelig tilgang til slik beskyttelse. Det kan ikke den katolske kirkes talsmenn snakke seg bort fra. De gjør valg ut fra normer og etikk som til syvende og sist bidrar til at unge mennesker kan risikere å sette livet til.

Jeg er ikke religiøs. Jeg har respekt for tro, etikk og normativitet likevel. Jeg har sett unge jenter i Vest-Afrika dø av illegal abort. Det er noe av det tristeste jeg har opplevd. Jeg synes det er verre enn å utføre tidligaborter. Jeg er entydig for selvbestemt abort. Jeg synes likevel det er greit med en tidsgrense for aborter, og er for at det skjer under trygge medisinske rammer.

Jeg er imot et språk der man kaller seksuell atferd som er annerledes enn det normative samleiet $i$ en normativ kjernefamilie for «promiskuøs». Det er mange grunner til at folk velger å ha sex, både gode og mindre gode. Jeg fordømmer ikke disse valgene, men forsøker å forstå dem, og ber unge mennesker være flinkere til å beskytte seg mot skadene, både vold, kjønnssykdommer, hivsmitte og uønskede graviditeter. Åpenhet, en ikke-fordømmende holdning, og tilgang på tjenester er svaret her. Der har ikke kirken gått i spissen, selv om de gjør mye annet veldig bra.

Ikke engang menneskerettighetserklæringene fremmer det synet at embryoer har like stor «rett» som fødte individer. Jeg deler ikke kirkens syn på fosterets «rettigheter». Respekt for levende mennesker er viktig, men i det ligger også en dyp respekt for individuelle skjebner og individuelle valg. Kirken har vært svært tvetydig her, $i$ en instans beatifiserte de en kvinne som valgte å dø fremfor å ta en abort som kunne reddet livet hennes. Jeg har opplevd kvinner i Norge som er svært syke - f.eks. av kreft og som dersom de blir gravide, kan risikere å bli mye sykere. Hva mener kirken jeg skal tilby dem?

\section{Johanne Sundby}

Avdeling for samfunnsmedisin

Universitetet i Oslo

Johanne Sundby (f. 1951) er gynekolog, professor i samfunnsmedisin og arbeider med reproduktiv helse i Afrika.

Ingen oppgitte interessekonflikter.

\section{Litteratur}

1. Røger M, Bleken H. Etikk og reproduktiv helse. Tidsskr Nor Legeforen 2011; 131: 2334-5.

2. Austveg B, Sundby J. Reproduktiv helse - tusenårsmålet lengst fra oppnåelse. Tidsskr Nor Legeforen 2011: 131: 1907-9 